\title{
Penerapan Logika Fuzzy Tsukamoto pada Penilaian Mutu Air Mineral (Studi Kasus PDAM Kota Bengkulu)
}

\author{
Rozali Toyib $^{1}$,Yulia Darnita ${ }^{2}$, Rizki Hidayat ${ }^{3}$ \\ Program Studi Informatika, FakultasTeknik Universitas Muhammadiyah Bengkulu \\ ${ }^{1}$ Rozalitoyib@gmail.com, ${ }^{2}$ yuliadarnita@gmai.com, ${ }^{3}$ rizkihidayat@gmail.com
}

\begin{abstract}
The problem of drinking water especially miniral water can not be removed from the water supply itself and the source of raw water used, PDAM Water Company) Bengkulu city as one of the water supply for the people of Bengkulu city where the source of its raw water comes from the river where in the downstream of the river many activities of society and mining, of course this will affect the water quality itself The system of eating calculations using the next Fuzzy Tsukamoto method is the calculation steps undertaken by the system: The first step of Fuzzy Tsukamoto method is fuzzyfikasi / calculate the degree of membership of each variable. After the formation of variables and fuzzyfication sets thereafter formed the corresponding rule by retrieving the data based on the experience of decision making and the decision rule obtained from the combination of each fuzzy set. After 7 (seven) experiments from 1 am to 4 pm with $\mathrm{pH}$ levels ranging from 35.7 to 48.5 , the remaining chlorine 0, DHL ranges from 208 to 226.3, the TDS ranges from 104 to 117.5 , the water quality is between 7,126 to 7,904 Good quality water quality based on NTU that has a minimum value of 0 and a maximum value of 5 , from the test system obtained a very interesting answer $47 \%$, attract $45 \%$, and not draw $8 \%$, the main factor determining the quality of water is the source of raw water itself, the less pollution in the downstream the better the quality of water produced.
\end{abstract}

Keywords: fuzzy, tsukamoto, water, minerals.

Intisari : Persoalan air minum khususnya air miniral tidak bisa dilepas dari penyedia air itu sendiri dan sumber air baku yang digunakan, Perusahan Air Minum PDAM) kota Bengkulu sebagai salah satu penyuplai air untuk masyarakat kota Bengkulu dimana sumber air bakunya berasal dari sungai dimana di hilir sungai tersebut banyak aktivitas masyarakat dan pertambangan, tentu hal ini akan mempengaruhi mutu air itu sendiri Sistem makan melakukan perhitungan menggunakan metode Fuzzy Tsukamoto berikutnya merupakan langkah-langkah perhitungan yang dilakukan oleh sistem:Langkah pertama metode Fuzzy Tsukamoto adalah fuzzyfikasi /menghitung derajat keanggotaan masing-masing variable. Setelah Pembentukan variable dan himpunan fuzzyfikasi selanjtunya dibentuk aturan besesuaian dengan mengambil data berdasarkan pengalaman keputusan dari pembuatan keputuasan dan aturan keputusan diperoleh dari kombinasi dari masing himpunan fuzzy. Setelah dilakukan 7 (tujuh) kali percobaan dari jam 01.00 sampai jam 24.00 dengan tingkat pH berkisar 35.7 sampai 48.5, sisa chlor 0, DHL berkisar 208 sampai 226.3, TDS berkisar 104 sampai 117.5,mutu air antara 7.126 sampai 7.904 keterangan mutu air baik dengan ketentuan Kualitas mutu air yang baik berdasarkan NTU yang memiliki nilai minimal 0 dan nilai maksimal 5, dari hasil pengujian sistem diperoleh jawaban sangat menarik $47 \%$, menarik $45 \%$, dan tidak menarik $8 \%$, faktor Utama penentuan mutu air adalah sumber air baku itu sendiri, semakin sedikit pencemaran di hilirnya maka semakin bagus mutu air yang dihasilkan.

Kata kunci: fuzzy, tsukamoto, air, mineral.

\section{Pendahuluan}

Perusahaan Daerah Air Minum (PDAM) Perusahaan Daerah Air Minum (PDAM) Bengkulu telah ada sejak zaman beland, yaitu pada tahun 1929 dengan nama Bengkoeloen Water Leideng Bedrijf. Kemudian setelah tahun 1945 dikelola oleh salah satu seksi DPU, yaitu seksi Seksi saluran Air Minum. Pada tahun1974 dengan Perda Kota Madia Dati II Bengkulu Nomor: 01/1-3/HUK/1974 tanggal 22 November 1974 di bentuk perusahan daerah air minum dengan namaPerusahan Daerah Air Minum Kotamadya Daerah Tingkat II Bengkulu, maksud didirikan PDAM adalah memberi jasa dan menyelenggarakan kemanfaatan umum dengan menyediakan air minum yang sehat dan memenuhi syarat kesehatan secara terus menerus. Tujuan perusahaan adalah turut serta dalam melaksanakan pembangunan daerah Kota Bengkulu melalui penyediaan dan pendistribusian air bersih/air minum bagi masyarakat di dalam wilayah Kota Bengkulu.

Sumber utama air baku Perusahan Air Minum (PDAM) Kota Bengkulu berasal dari dua sumber yaitu 
Sungai Bangkahulu dan Air Nalas, dari dua sumber inilah air dipasok dan dilakukan pengolahan pada instalasi yang dipunyai oleh perusahan daerah ini. Sungai Bangkaulu ini meruapakan gabungan beberapa sungai-sungai kecil yang mengalir dari sumber mata air dari hutan lindung yang dihulunya yang melewati pemukiman penduduk dan areal tambang batu bara yang dikelola olah perusahan-perusahan nasional dan multinasional, memang dari segi investasi sangat menguntungkan karena akan menambah inkam daerah dari sumber non pertanian yang menyumbang terbesar darin restribusi dan juga pajak.

Perusahan-perusahan tambang ini rata-rata areal tambangnya terletakn di anak-anak sunggai yang alirannya menujuh ke Sungai Bangkahulu, banyak aktifitas domestik dan industri disepanjanga sungai menimbulkan perubahan kualitas dan kuantitas air, apa bila musim hujan kemungkin besar dampaknya tidak terlalu karena debet air yanag cukup banyak tetapi kalau musim kemarau maka pengaruht besar sekali terhadap kualitas air baku sebelum diolah.

Sebagaian besar wilayah Kota Bengkulu daerahnya berawa-rawa maka air tanahnya tidak bisa digunakan karena mengandung logam dan berwarna kekuningkuningan, karena hal ini banyak penduduk mengandalakan pasokan air untuk kebutuhan mereka dari Perusahan Air Minum Daerah (PDAM), keluhan yang banyak dari konsumen ada kalanya air yang distribusikan ke pelagan-pelanggan di Kota Bengkulu yang terlihat keruh dan tercium bau yang kurang mengenakan seperti tidak layak untuk di kosumsi apa lagi bila tiba musim kemarau panjang, untuk menjaga agar mutu air yang disalurkan ke pelanggan layak minum maka perlu dilakukan serangkaian pengujian terlebih dahulu.

Metode Fuzzy Tsukamoto ini akan digunakan untuk penilaian mutu air mineral berdasarkan NTU, PH, dan Sisa Clhor, data dari NTU, PH, dan Sisa Clhor adalah variabel-variabel yang akan direpresentasikan dengan fungsi keanggotaan fuzzy, dengan menggunakan sistem ini menghasilkan penilaian mutu air mineral menjadi lebih cepat dan akurat, kemudian data data tersebut akan diolah dengan metode fuzzy Tsukamoto dan akan menampilkan keluaran (output) berupa penilaian mutu air mineral.

\section{TinJauAn PUStaka}

\section{A. Persyaratan Kualitas Air Minum}

Berdasarkan Peraturan Menteri Kesehatan Republik Indonesia Nomor 492/Menkes/Per/IV/2010 persyararatan kualitas air minum yang salah satu bunyi yaitu bahwa agar air minum yang dikosumsi masyarakat tidak menimbulkan gangguan kesehatan perlu ditetapkan persyaratan kesehatan kualitas air minum, air minum adalah air yang melalui proses pengolahan atau tanpa proses pengolahan yang memenuhi syarat kesehatan dan dapat langsung diminum dan setiap penyelenggara air minum wajib menjamin air minum yang diproduksinya aman bagi kesehatan. Air minum aman bagi kesehatan apabila memenuhi persyaratan fisika, mikrobiologis, kimiawi dan radioaktif yang dimuat dalam parameter wajib dan parameter tambahan.

\section{Parameter Wajib}

\begin{tabular}{|c|c|c|c|}
\hline No & Jenis Parameter & Satuan & $\begin{array}{c}\text { Kadar } \\
\text { Maksimum } \\
\text { yang } \\
\text { diperbolehkan }\end{array}$ \\
\hline \multirow[t]{12}{*}{1} & $\begin{array}{l}\text { Parameter yang } \\
\text { berhubungan langsung } \\
\text { dengan kesehatan }\end{array}$ & & \\
\hline & $\begin{array}{l}\text { a. Parameter } \\
\text { Mikrobiologi }\end{array}$ & & \\
\hline & 1) E.Coli & $\begin{array}{c}\text { Jumlah } \\
\text { per } 100 \\
\text { ml sampel }\end{array}$ & 0 \\
\hline & $\begin{array}{l}\text { 2) Total Bakteri } \\
\text { Koliform }\end{array}$ & $\begin{array}{c}\text { Jumlah } \\
\text { per } 101 \\
\text { ml sampel } \\
\end{array}$ & 0 \\
\hline & b. Kimia an-organik & & \\
\hline & 1) Arsen & $\mathrm{mg} / \mathrm{l}$ & 0,01 \\
\hline & 2) Fluorida & $\mathrm{mg} / \mathrm{l}$ & 1,5 \\
\hline & 3) Total Kromium & $\mathrm{mg} / \mathrm{l}$ & 0,05 \\
\hline & 4) Kadmium & $\mathrm{mg} / \mathrm{l}$ & 0,003 \\
\hline & $\begin{array}{l}\text { 5) Nitri, (sebagai } \\
\text { NO2*) }\end{array}$ & $\mathrm{mg} / \mathrm{l}$ & 3 \\
\hline & $\begin{array}{l}\text { 6) Nitrat, (sebagai } \\
\mathrm{NO}^{*} \text { ) }\end{array}$ & $\mathrm{mg} / \mathrm{l}$ & 50 \\
\hline & 7) Sianida & $\mathrm{mg} / \mathrm{l}$ & 0,07 \\
\hline
\end{tabular}




\begin{tabular}{|c|c|c|c|}
\hline No & Jenis Parameter & Satuan & $\begin{array}{c}\text { Kadar } \\
\text { Maksimum } \\
\text { yang } \\
\text { diperbolehkan }\end{array}$ \\
\hline & 8) Selenium & $\mathrm{mg} / \mathrm{l}$ & 0,01 \\
\hline 2 & $\begin{array}{l}\text { Parameter yang tidak } \\
\text { langsung berhubungan } \\
\text { dengan kesehatan }\end{array}$ & & \\
\hline & a. Parameter Fisik & & Tidak berbau \\
\hline & 1) Bau & & 15 \\
\hline & 2) Warna & $\mathrm{TCU}$ & 500 \\
\hline & $\begin{array}{l}\text { 3) Total zat padat } \\
\text { terlarut (TDS) }\end{array}$ & $\mathrm{mg} / \mathrm{l}$ & 5 \\
\hline & 4) Kekeruhan & $\mathrm{NTU}$ & Tidak berasa \\
\hline & 5) Rasa & $\mathrm{C}$ & suhu udara +3 \\
\hline & 6) Suhu & & 0,2 \\
\hline & b. Parameter Kimiawi & $\mathrm{mg} / 1$ & 0,3 \\
\hline & 1) Alumunium & $\mathrm{mg} / 1$ & 500 \\
\hline & 2) Besi & $\mathrm{mg} / \mathrm{l}$ & 250 \\
\hline & 3) Kesadahan & $\mathrm{mg} / 1$ & 0,4 \\
\hline & 4) Kholorida & $\mathrm{mg} / 1$ & $6,5-85$ \\
\hline & 5) Mangan & $\mathrm{mg} / 1$ & 3 \\
\hline & 6) pH & $\mathrm{mg} / 1$ & 250 \\
\hline & 7) Seng & $\mathrm{mg} / 1$ & 2 \\
\hline & 8) Sulfat & $\mathrm{mg} / 1$ & 1,5 \\
\hline & 9) Tembaga & \\
\hline & 10) Amonia & & \\
\hline
\end{tabular}

\section{Parameter Tambahan}

\begin{tabular}{|c|c|c|c|}
\hline No & Jenis Parameter & Satuan & $\begin{array}{c}\text { Kadar Maksimum } \\
\text { yang diperbolehkan }\end{array}$ \\
\hline 1 & KIMIAWI & & \\
\hline \multirow[t]{10}{*}{ a. } & Bahan Onorganik & & \\
\hline & Air Raksa & $\mathrm{mg} / \mathrm{l}$ & 0,001 \\
\hline & Antimon & $\mathrm{mg} / \mathrm{l}$ & 0,02 \\
\hline & Barium & $\mathrm{mg} / \mathrm{l}$ & 0,7 \\
\hline & Baron & $\mathrm{mg} / \mathrm{l}$ & 0,5 \\
\hline & Molybdenum & $\mathrm{mg} / \mathrm{l}$ & 0,07 \\
\hline & Nikel & $\mathrm{mg} / \mathrm{l}$ & 0,08 \\
\hline & Sodium & $\mathrm{mg} / \mathrm{l}$ & 200 \\
\hline & Timbal & $\mathrm{mg} / \mathrm{l}$ & 0,01 \\
\hline & Uranium & $\mathrm{mg} / \mathrm{l}$ & 0,015 \\
\hline \multirow[t]{24}{*}{ b. } & Bahan Organik & $\mathrm{mg} / \mathrm{l}$ & \\
\hline & Zat Organik (KMn04) & $\mathrm{mg} / \mathrm{l}$ & 10 \\
\hline & Deterjen & & 0,05 \\
\hline & Chlorinate alkanes & & \\
\hline & Carbon tetrachloride & $\mathrm{mg} / \mathrm{l}$ & 0,004 \\
\hline & Dichloromethane & $\mathrm{mg} / \mathrm{l}$ & 0,02 \\
\hline & 1,2-Dichloroethane & $\mathrm{mg} / \mathrm{l}$ & 0,05 \\
\hline & Chlorinate ethenes & & \\
\hline & 1,2-Dichloroethane & $\mathrm{mg} / \mathrm{l}$ & 0,05 \\
\hline & Trichloroethene & $\mathrm{mg} / \mathrm{l}$ & 0,02 \\
\hline & Tetrachloroethene & $\mathrm{mg} / \mathrm{l}$ & 0,04 \\
\hline & $\begin{array}{l}\text { Aromatic } \\
\text { hydrocarbons }\end{array}$ & & \\
\hline & Benzene & $\mathrm{mg} / \mathrm{l}$ & 0,01 \\
\hline & Toluene & $\mathrm{mg} / \mathrm{l}$ & 0,7 \\
\hline & Xylenes & $\mathrm{mg} / \mathrm{l}$ & 0,5 \\
\hline & Ethylbenzene & $\mathrm{mg} / \mathrm{l}$ & 0,3 \\
\hline & Styrene & $\mathrm{mg} / \mathrm{l}$ & 0,02 \\
\hline & Chlorinated Benzenez & & \\
\hline & $\begin{array}{l}\text { 1,2-Dichlorobenzene } \\
\text { (1,2-DCB) }\end{array}$ & $\mathrm{mg} / \mathrm{l}$ & 1 \\
\hline & $\begin{array}{l}\text { 1,4-Dichlorobenzene } \\
\text { (1,4-DCB) }\end{array}$ & $\mathrm{mg} / \mathrm{l}$ & 0,3 \\
\hline & Lain-lain & & \\
\hline & $\begin{array}{l}\text { Di(2- } \\
\text { ethylhexyl)phthalate }\end{array}$ & $\mathrm{mg} / \mathrm{l}$ & 0.008 \\
\hline & Acrylamide & $\mathrm{mg} / \mathrm{l}$ & 0.0005 \\
\hline & Epichlorohydrin & $\mathrm{mg} / \mathrm{l}$ & 0.0004 \\
\hline
\end{tabular}

\begin{tabular}{|c|c|c|c|}
\hline No & Jenis Parameter & Satuan & $\begin{array}{c}\text { Kadar Maksimum } \\
\text { vang diperbolehkan }\end{array}$ \\
\hline & Hexachlorobutadiene & $\mathrm{mg} / \mathrm{l}$ & 0.0006 \\
\hline & $\begin{array}{l}\text { Ethylenediaminetetraa } \\
\text { cetic }\end{array}$ & & \\
\hline & acid (EDTA) & $\mathrm{mg} / \mathrm{l}$ & 0,6 \\
\hline & $\begin{array}{l}\text { Nitrilotriaceti aci } \\
\text { (NTA) }\end{array}$ & $\mathrm{mg} / \mathrm{l}$ & 0,2 \\
\hline \multirow[t]{33}{*}{$\mathrm{c}$} & Pestisida & $\mathrm{mg} / \mathrm{l}$ & 0,02 \\
\hline & Alachlor & $\mathrm{mg} / \mathrm{l}$ & 0,01 \\
\hline & Aldicarb & $\mathrm{mg} / \mathrm{l}$ & 0,00003 \\
\hline & Aldrin dan dieldrin & $\mathrm{mg} / \mathrm{l}$ & 0,002 \\
\hline & Atrazine & $\mathrm{mg} / \mathrm{l}$ & 0,007 \\
\hline & Carbofuran & $\mathrm{mg} / \mathrm{l}$ & 0,0002 \\
\hline & Chlordane & $\mathrm{mg} / \mathrm{l}$ & 0,03 \\
\hline & Chlorotoluron & $\mathrm{mg} / \mathrm{l}$ & 0,001 \\
\hline & DTT & $\mathrm{mg} / \mathrm{l}$ & 0,001 \\
\hline & $\begin{array}{l}\text { 1,2-Dibromo-3- } \\
\text { chloropropane }\end{array}$ & & \\
\hline & $(\mathrm{DBCP})$ & $\mathrm{mg} / \mathrm{l}$ & 0,0001 \\
\hline & $\begin{array}{l}2,4- \\
\text { Dichloroprophen0xya } \\
\text { cetic }\end{array}$ & & \\
\hline & acid $(2,4-D)$ & $\mathrm{mg} / \mathrm{l}$ & 0.03 \\
\hline & 1,2-Dichloropropane & $\mathrm{mg} / \mathrm{l}$ & 0,04 \\
\hline & Isoproturon & $\mathrm{mg} / \mathrm{l}$ & 0,009 \\
\hline & Lindane & $\mathrm{mg} / \mathrm{l}$ & 0,002 \\
\hline & MCPA & $\mathrm{mg} / \mathrm{l}$ & 0,002 \\
\hline & Methoxychlor & $\mathrm{mg} / \mathrm{l}$ & 0,02 \\
\hline & Metolachlor & $\mathrm{mg} / \mathrm{l}$ & 0,01 \\
\hline & Molinatc & $\mathrm{mg} / \mathrm{l}$ & 0,006 \\
\hline & Pendimethalin & $\mathrm{mg} / \mathrm{l}$ & 0,02 \\
\hline & $\begin{array}{l}\text { Pentachlorophenol } \\
\text { (PCP) }\end{array}$ & $\mathrm{mg} / \mathrm{l}$ & 0,009 \\
\hline & Permethrin & $\mathrm{mg} / \mathrm{l}$ & 0,3 \\
\hline & Simazine & $\mathrm{mg} / \mathrm{l}$ & 0,002 \\
\hline & Trifluralin & $\mathrm{mg} / \mathrm{l}$ & 0,02 \\
\hline & $\begin{array}{l}\text { Chlorophenoxy } \\
\text { herbicides }\end{array}$ & & \\
\hline & $\begin{array}{l}\text { selain 2,4-D dan } \\
\text { MCPA }\end{array}$ & & \\
\hline & $2,4-\mathrm{DB}$ & $\mathrm{mg} / \mathrm{l}$ & 0,090 \\
\hline & Dichlorop & $\mathrm{mg} / \mathrm{l}$ & 0,10 \\
\hline & Fenoprop & $\mathrm{mg} / \mathrm{l}$ & 0,009 \\
\hline & Mecroprop & $\mathrm{mg} / \mathrm{l}$ & 0,001 \\
\hline & $\begin{array}{l}2,4,5- \\
\text { Trichlorophenoxyaceti } \\
\text { c }\end{array}$ & & \\
\hline & acid & $\mathrm{mg} / \mathrm{l}$ & 0,010 \\
\hline \multirow[t]{18}{*}{$\mathrm{d}$} & Desnfektan dan hasil & & \\
\hline & $\begin{array}{l}\text { sampingannya } \\
\text { Desinfektan }\end{array}$ & & \\
\hline & Chlorine & $\mathrm{mg} / \mathrm{l}$ & 5 \\
\hline & Hasil Sampingan & & \\
\hline & Bromate & $\mathrm{mg} / \mathrm{l}$ & 0,01 \\
\hline & Chhlorate & $\mathrm{mg} / \mathrm{l}$ & 0,7 \\
\hline & Chlorite & $\mathrm{mg} / \mathrm{l}$ & 0,7 \\
\hline & Chlorophenenols & & \\
\hline & 2,4,6 -Trichloropheno & $\mathrm{mg} / \mathrm{l}$ & \\
\hline & $(2,4,6-\mathrm{TCP})$ & $\mathrm{mg} / \mathrm{l}$ & 0,2 \\
\hline & Bromoform & $\mathrm{mg} / \mathrm{l}$ & 0,1 \\
\hline & $\begin{array}{l}\text { Dibromochloromethan } \\
\text { e (DBCM) }\end{array}$ & $\mathrm{mg} / \mathrm{l}$ & 0,1 \\
\hline & $\begin{array}{l}\text { Bromodichloromethan } \\
\text { e (BDCM) }\end{array}$ & $\mathrm{mg} / \mathrm{l}$ & 0,06 \\
\hline & Chloroform & $\mathrm{mg} / \mathrm{l}$ & 0,3 \\
\hline & $\begin{array}{l}\text { Chlorinated acetic } \\
\text { acids }\end{array}$ & & \\
\hline & Dichloroacetic acid & $\mathrm{mg} / \mathrm{l}$ & 0,05 \\
\hline & Trichloroacetic Acid & $\mathrm{mg} / \mathrm{l}$ & 0,02 \\
\hline & Chloral hydrate & & \\
\hline
\end{tabular}




\begin{tabular}{|c|c|c|c|}
\hline No & Jenis Parameter & Satuan & $\begin{array}{c}\text { Kadar Maksimum } \\
\text { yang diperbolehkan }\end{array}$ \\
\hline & $\begin{array}{l}\text { Halogenated } \\
\text { acetonitrilies }\end{array}$ & & \\
\hline & Dichloroacetonitrile & $\mathrm{mg} / \mathrm{l}$ & 0,02 \\
\hline & Dibromoacetonitrile & $\mathrm{mg} / \mathrm{l}$ & 0,07 \\
\hline & $\begin{array}{l}\text { Cyanogen chloride } \\
\text { (sebagai } \mathrm{CN} \text { ) }\end{array}$ & $\mathrm{mg} / \mathrm{l}$ & 0,07 \\
\hline 2 & RADIOAKTIFITAS & & \\
\hline & Gross alpha activity & $\mathrm{Bq} / 1$ & 0,1 \\
\hline & Gros Beta Activity & $\mathrm{Bq} / 1$ & 1 \\
\hline
\end{tabular}

\section{B. Logika Fuzzy}

Konsep tentang logika fuzzy pertama kali diperkenalkan oleh Prof. Lotfi Astor Zadeh pada tahun 1962. Logika fuzzy adalah metodologi sistem kontrol untuk memecahkan masalah, cocok untuk diimplementasikan pada sistem, sistem yang sederhana, embedded sistem, sistem kecil, jaringan PC, multi-chanel atau workstation berbasis akuisisi data, dan sistem kontrol. Metodologi ini dapat diterapkan pada perangkat keras dan perangkat lunak maupun kombinasi keduanya. Dalam logika klasis dinyatakan segala sesuatu bersifat biner, yang artinya adalah hanya mempunyai dua kemungkinan tidak lebih, "Benar atau Salah", "Ya atau Tidak", "Baik atau Buruk", dan lain-lain. Karena itu, semua dapat mempunyai nilai keanggotaan 0 atau 1. Tetapi, dalam logika fuzzy dimungkinkan nilai keanggotaan berada diantara 0 dan 1. Artinya, bisa saja keadaan mempunyai dua nilai "Ya dan Tidak", "Benar dan Salah", "Baik dan Buruk" secara bersamaan, tetapi besar nilainya tergantung pada bobot keanggotaan yang dimiliki. Logika fuzzy bisa digunakan di berbagai bidang, misal seperti pada sistem diagnosia penyakit (dalam bidang kedokteran), riset operasi (dalam bidang ekonomi), pemodelan sistem pemasaran, prediksi terjadinya gempa bumi, kendali kualitas air, 4 klasifikasi dan pencocokan pola (dalam bidang teknik). (Yaumas .A Maulana , 2014)
C. Metode Tsukamoto

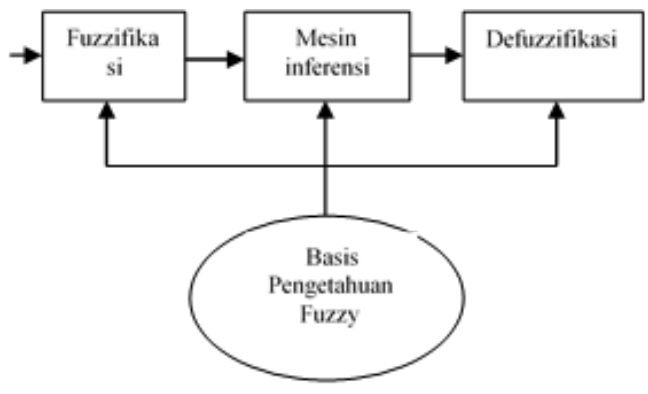

Gambar 1. Metode Tsukamoto

1. Fuzzyfikasi

2. Pembentukan basis pengetahuan fuzzy (Rule dalam bentuk IF...THEN)

3. Mesin Inferensi (fungsi implikasi MaxMin atau Dot-Product)

4. Defuzzyfikasi Banyak cara untuk melakukan defuzzyfikasi, diantaranya metode berikut:

a. Metode Rata-Rata (Average)

b. Metode Titik Tengah (Center Of Area)

(Yaumas A Maulana (2014)

\section{Metodologi Penelitian}

\section{A. Pengumpulan Data}

Menggunakan observasi untuk melihat secara langsung ke tempat penelitian dalam Perusahaan Daerah Air Minum (PDAM) Perusahaan Daerah Air Minum (PDAM) Bengkulu, melihat secara langsung bagaimana pengolahan air minum yang ada disana serta menggali datan dengan bertanya secara langsung proses di lakukan dan melihat proses pemurnian air sehingga layak minum.

\section{B. Perancangan Aplikasi}

Berikut ini merupakan flowchart penerapan Logika fuzzy Tsukamoto pada penilaian mutu air dapat dilihat pada Gambar 2. 


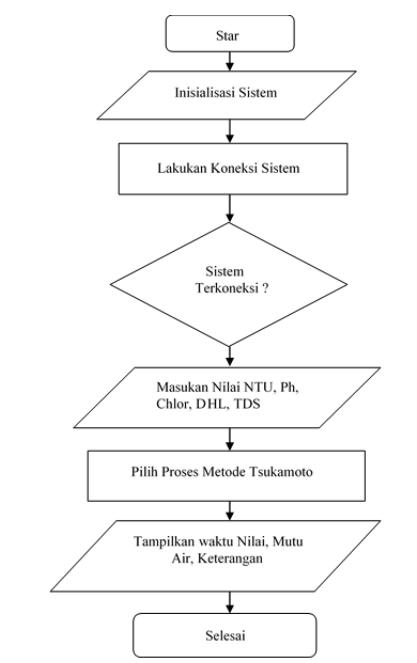

Gambar 2. Flowchart Fuzzy Tsukamoto

Proses dalam perhitungan Fuzzy Tsukamoto pada gambar diatas diambil 1 contoh sampel adalah sebagai berikut:
a. NTU
b. $\mathrm{pH}$
$: 7.12$
c. DHL
$: 226$
d. TDS
$: 113$
e. Sisa khlor : 0

Adapun proses melakukan perhitungan Tsukamoto dalam menentukan mutu air adalah sebagai berikut:

1. Menentukan variabel yang terkait dalam proses dan fungsi fuzzyfikasi yang sesuai.

2. Variabel ukuran terdiri dari 2 nilai linguistik yaitu minimal dan maksimal. Maka fungsi keanggotaan dirumuskan sebagai berikut :

a. Variabel NTU terdiri dari 2 nilai linguistik yaitu minimal dan maksimal. Maka fungsi keanggotaan dirumuskan sebagai berikut

$$
\begin{aligned}
& \mu \text { NTU Minimal }[x]=\left\{\begin{array}{c}
1 ; \quad x \leq 2 \\
\frac{0-x}{2} ; 2 \leq x \leq 4 \\
; \quad x \geq 0
\end{array}\right. \\
& =\frac{20}{2}=\frac{10}{5} \\
& \mathrm{Z}=2 \\
& \mu \text { NTU Maksimal }[x]=\left\{\begin{array}{cc}
0 & ; \quad x \leq 2 \\
\frac{x-4}{2} ; & x \leq x \leq 4 \\
1 & x \geq 0
\end{array}\right. \\
& =\frac{4}{2}=2 \\
& \mathrm{Z}=2
\end{aligned}
$$

b. Variabel $\mathrm{pH}$ terdiri dari 2 nilai linguistik yaitu minimal dan maksimal. Maka fungsi keanggotaan dirumuskan sebagai berikut $\mu \mathrm{pH}$ Minimal $[x]=\left\{\begin{array}{cr}1 ; & x \leq 2 \\ \frac{6.5-x}{2} ; & \leq x \leq 6.5 \\ 0 & x \geq 6.5\end{array}\right.$

$$
\begin{aligned}
& =\frac{6.5}{2}=3.25 \\
& \mathrm{Z}=3.25 \\
& \mu \mathrm{pH} \text { Maksimal }=\left\{\begin{array}{c}
0 ; \quad x \leq 2 \\
\frac{8,5-6.5}{2} ; 2 \leq x \leq 8,5 \\
1 \quad x \geq 6,5
\end{array}\right. \\
& =\frac{8,5}{2}=4.25 \\
& Z=4.25
\end{aligned}
$$

c. Variabel DHL terdiri dari 2 nilai linguistik yaitu minimal dan maksimal. Maka fungsi keanggotaan dirumuskan sebagai berikut

$$
\mu \text { DHL Minimal }[x]=\left\{\begin{array}{cc}
1 ; & x \leq 2 \\
\frac{19-x}{2} ; & \leq x \leq 19 \\
0 & x \geq 19
\end{array}\right.
$$

$$
=\frac{19}{2}=\frac{9.5}{5}
$$$$
\mathrm{Z}=1
$$

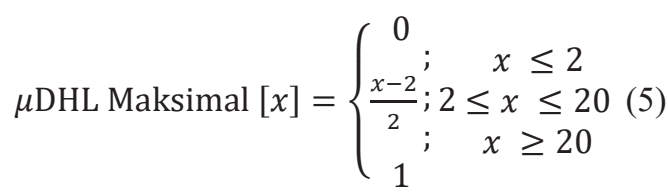

$$
\begin{aligned}
& =\frac{20}{2}=\frac{10}{5} \\
& Z=2
\end{aligned}
$$

d. Variabel TDS terdiri dari 2 nilai linguistik yaitu Minimal dan Maksimal. Maka fungsi keanggotaan dirumuskan sebagai berikut :

$$
\begin{aligned}
& \mu \text { TDS Minimal } 2[z]=\left\{\begin{array}{c}
1 ; \quad z \leq 2 \\
\frac{97-z}{2} ; 2 \leq z \leq 97 \\
; \quad z \geq 97
\end{array}\right. \\
& =\frac{97}{2}=\frac{48.5}{5} \\
& Z=9.7 \\
& \mu \text { TDS Maksimal } 1=\left\{\begin{array}{cc}
1 & ; \\
\frac{z-100}{2} ; & z>100<z \leq 100 \\
0 & z \leq 100
\end{array}\right.
\end{aligned}
$$




$$
\begin{aligned}
& =\frac{100}{2}=\frac{50}{5} \\
& Z=10
\end{aligned}
$$

1. Menentukan nilai keanggotaan
a. NTU
b. $\mathrm{pH}$
c. DHL
d. TDS
e. Sisa Clhor

2. Rule (Inferensi Engine)

Tabel 3. Rule (Inferensi Engine)

\begin{tabular}{|c|c|c|}
\hline Komponen Air & Nilai Maksimal & Nilai Minimal \\
\hline NTU & 4 & 0 \\
\hline pH & 8,5 & 6,5 \\
\hline Sisa Clhor & 0 & 0 \\
\hline DHL & 21 & 19 \\
\hline TDS & 100 & 97 \\
\hline
\end{tabular}

Tabel 4. Komponen Penilaian

\begin{tabular}{|c|c|c|}
\hline Komponen Air & Nilai Maksimal & Nilai Minimal \\
\hline NTU & 4 & 0 \\
\hline pH & 8,5 & 6,5 \\
\hline Sisa Clhor & 0 & 0 \\
\hline DHL & 21 & 19 \\
\hline TDS & 100 & 97 \\
\hline
\end{tabular}

a. Aspek Penilaian NTU

Tabel 5. Aspek Penilaian NTU

\begin{tabular}{|c|c|}
\hline Interval Penilaian & Keterangan \\
\hline $0-2$ & Buruk \\
\hline $3-4$ & Baik \\
\hline
\end{tabular}

b. Aspek Penilaian $\mathrm{pH}$

Tabel 6 . Aspek Penilaian pH

\begin{tabular}{|c|c|}
\hline Interval Penilaian & Keterangan \\
\hline $6-6,4$ & Buruk \\
\hline $6,5-8,5$ & Baik \\
\hline
\end{tabular}

c. Aspek Penilaian TDS

Tabel 7. Aspek Penilaian TDS

\begin{tabular}{|c|c|}
\hline Interval Penilaian & Keterangan \\
\hline $10-12$ & Buruk \\
\hline $19-25$ & Baik \\
\hline
\end{tabular}

d. Aspek Penilaian DHL

Tabel 8. Aspek Penilaian DHL

\begin{tabular}{|c|c|}
\hline Interval Penilaian & Keterangan \\
\hline $15-18$ & Buruk \\
\hline $19-21$ & Baik \\
\hline
\end{tabular}

e. Aspek Penilaian Sisa Chlor

Tabel 9. Aspek Penilaian Clhor

\begin{tabular}{|c|c|}
\hline Interval Penilaian & Keterangan \\
\hline 0 & Buruk \\
\hline $1-3$ & Baik \\
\hline
\end{tabular}

Adapun rule yang digunakan adalah sebagai berikut :

1. IF NTU Buruk AND pH Baik AND Sisa Clhor 0 AND DHL Baik AND TDS Baik THEN Mutu Air Buruk.

2. IF NTU Baik AND pH Buruk AND Sisa Clhor 0 AND DHL Baik AND TDS Baik THEN Mutu Air Buruk.

3. IF NTU Baik AND pH Baik AND Sisa Clhor 0 AND DHL Buruk AND TDS Baik THEN Mutu Air Buruk.

4. IF NTU Baik AND pH Baik AND Sisa Clhor 0 AND DHL Baik AND TDS Buruk THEN Mutu Air Buruk.

5. IF NTU Baik AND pH Baik AND Sisa Clhor 1 AND DHL Buruk AND TDS Baik THEN Mutu Air Baik

6. IF NTU Baik AND pH Baik AND Sisa Clhor 1 AND DHL Baik AND TDS Baik THEN Mutu Air Baik

7. IF NTU Baik AND pH Baik AND Sisa Clhor 1 AND DHL Baik AND TDS Buruk THEN Mutu Air Baik

8. IF NTU Baik AND pH Baik AND Sisa Clhor 0 AND DHL Baik AND TDS Baik THEN Mutu Air Baik

Defuzzifikasi

$$
\begin{aligned}
Z & =\frac{\alpha^{1} z^{1}+\alpha^{1} z^{2}+\alpha^{1} z^{3}+\alpha^{1} z^{4}}{4} \\
& =\frac{Z}{4 \times 2}
\end{aligned}
$$

\section{IMPLEMENTASI}

\section{A. Hasil}

Adapun hasil penelitian penerapan logika fuzzy tsukamoto pada penilaian mutu air mineral berdasarkan tingkat akurasi derajat standar mutu air mineral. Adapun langkah menjalankan penerapan 
logika fuzzy tsukamoto pada penilaian mutu air mineral adalah sebagai berikut :

\section{Tampilam Menu Index}

Tampilan menu index merupakan tampilan awal dari aplikasi Tsukamoto dalam mencari mutu air mineral, dalam menu index terdapat 4 menu, yaitu beranda, pengenalan mutu air, mutu air, dan tentang penulis. Adapun tampilan menu index ditunjukkan pada Gambar 3.

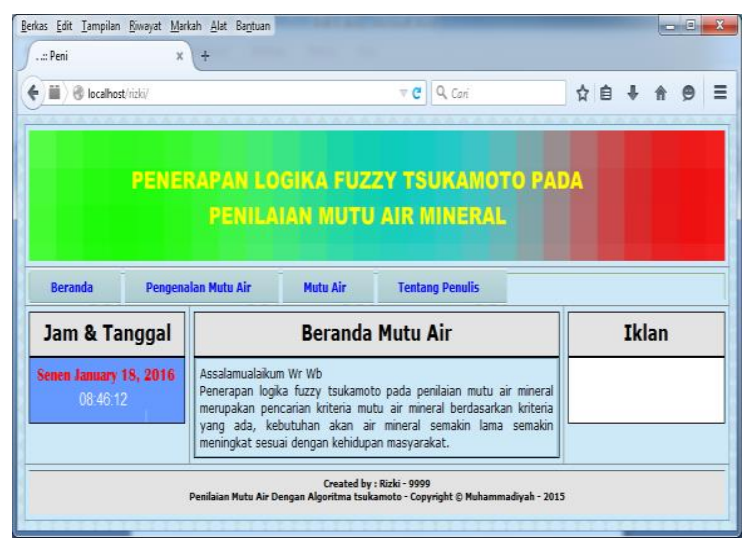

Gambar 3. Tampilam Menu Inde

\section{Tampilam Menu Pengenalan Mutu Air}

Tampilam menu pengenalan mutu air merupakan tampilan dari informasi secara detil tentang mutu air mineral, adapun tampilan menu pengenalan mutu air dapat dilihat pada gambar 4 .

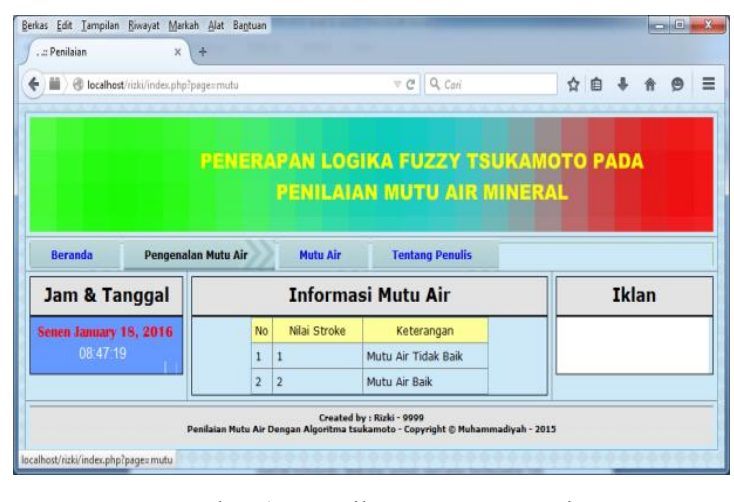

Gambar 4. Tampilam Menu Mutu Air

Tampilam menu Mutu air merupakan mutu air dengan metode Tsukamoto, pada metode ini dilakukan penilaian komponen mutu air dan komponen apa yang dapat menghasilkan mutu air. Pada metode Tsukamoto dilakukan proses pencarian berdasarkan rule yang diambil dari mutu air tersebut. Adapun Tampilam menu $\mathrm{pH}$ air dapat dilihat pada gambar 5.

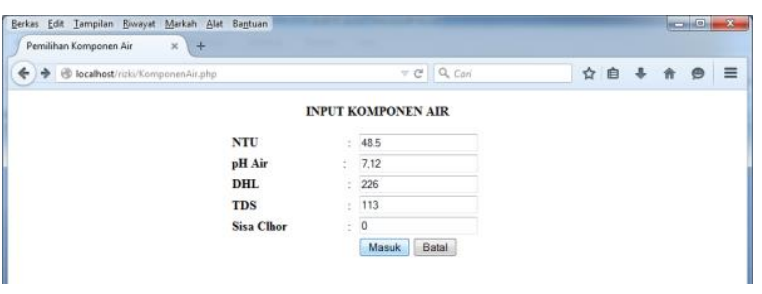

Gambar 5. Tampilan Menu Komponen Air

\section{B. Pembahasan}

Berdasarkan hasil pengujian yang dilakukan di PDAM Kota Bengkulu berdasarkan data perjam kuantitas air IPA Surabaya, yaitu :

Tabel 10. Pengujian Penilaian Air PDAM

\begin{tabular}{|c|c|c|c|c|c|c|l|}
\hline \multirow{2}{*}{ Jam } & \multicolumn{7}{|c|}{ Air Baku } \\
\cline { 2 - 8 } & $\begin{array}{c}\text { NT } \\
\mathrm{U}\end{array}$ & $\mathrm{pH}$ & $\begin{array}{c}\text { Sisa } \\
\mathrm{r}\end{array}$ & DHL & TDS & $\begin{array}{l}\text { Mut } \\
\text { u Air }\end{array}$ & $\begin{array}{l}\text { Keteranga } \\
\text { n }\end{array}$ \\
\hline $\begin{array}{c}01,0 \\
0\end{array}$ & 48.5 & $\begin{array}{c}7.1 \\
2\end{array}$ & 0 & $\begin{array}{c}226 . \\
3\end{array}$ & $\begin{array}{c}113 . \\
1\end{array}$ & $\begin{array}{c}7.90 \\
1\end{array}$ & $\begin{array}{l}\text { Mutu Air } \\
\text { Baik }\end{array}$ \\
\hline $\begin{array}{c}02,0 \\
0\end{array}$ & 45.3 & $\begin{array}{c}7.1 \\
1\end{array}$ & 0 & 225 & $\begin{array}{c}117 \\
5\end{array}$ & $\begin{array}{c}7.89 \\
8\end{array}$ & $\begin{array}{l}\text { Mutu Air } \\
\text { Baik }\end{array}$ \\
\hline $\begin{array}{c}03,0 \\
0\end{array}$ & 41.2 & $\begin{array}{c}7.1 \\
3\end{array}$ & 0 & $\begin{array}{c}222 . \\
7\end{array}$ & $\begin{array}{c}111 . \\
4\end{array}$ & $\begin{array}{c}7.64 \\
7\end{array}$ & $\begin{array}{l}\text { Mutu Air } \\
\text { Baik }\end{array}$ \\
\hline $\begin{array}{c}22,0 \\
0\end{array}$ & 37.1 & 7.2 & 0 & 208 & 104 & 7.12 & $\begin{array}{l}\text { Mutu Air } \\
\text { Baik }\end{array}$ \\
\hline $\begin{array}{c}23,0 \\
0\end{array}$ & 36.1 & $\begin{array}{c}7.1 \\
5\end{array}$ & 0 & 212 & 106 & 7.22 & $\begin{array}{l}\text { Mutu Air } \\
\text { Baik }\end{array}$ \\
\hline $\begin{array}{c}24,0 \\
0\end{array}$ & 35.7 & $\begin{array}{c}7.1 \\
2\end{array}$ & 0 & 212 & 106 & 7.21 & $\begin{array}{l}\text { Mutu Air } \\
\text { Baik }\end{array}$ \\
\hline
\end{tabular}

Ada beberapa alat bantu yang biasa digunakan :

1. NTU menggunakan alat $\mathrm{HACH}$

2. $\mathrm{pH}$ menggunakan alat $\mathrm{HACH}$

3. Sisa Clhor menggunakan alat Lovibond

4. DHL menggunakan alat $\mathrm{HACH}$

5. TDS menggunakan alat $\mathrm{HACH}$

Kualitas mutu air yang baik berdasarkan NTU yang memiliki nilai minimal 0 dan nilai maksimal 5 .

\section{Hasil Pengujian}

Hasil pengujian dengan menggunakan black box testing dan white box testing:

\section{Black Box}

Tabel 11. Pengujian Black Box

\begin{tabular}{|c|l|c|}
\hline $\begin{array}{c}\text { Proses yang } \\
\text { di uji }\end{array}$ & \multicolumn{1}{|c|}{ Skenario Pengujian } & \multicolumn{1}{|c|}{$\begin{array}{c}\text { Hasil yang } \\
\text { diharapkan }\end{array}$} \\
\hline $\begin{array}{c}\text { Input } \\
\text { Komponen }\end{array}$ & $\begin{array}{l}\text { 1. Masukkan 5 } \\
\text { komponen }\end{array}$ & Akan memberikan \\
\hline Air & air yaitu NTU, pH, & mutu air baik dan \\
\hline & $\begin{array}{l}\text { Air, DHL, TDS, Sisa } \\
\text { Clhor }\end{array}$ & tidak baik \\
\hline
\end{tabular}




\section{a. White Box}

Tabel 12. Pengujian White Box

\begin{tabular}{|c|l|c|c|c|}
\hline \multirow{2}{*}{ No } & \multicolumn{1}{|c|}{ Kriteria } & \multicolumn{3}{|c|}{ Persentase \% } \\
\cline { 3 - 5 } & & SM & M & TM \\
\hline 1 & $\begin{array}{l}\text { Program bersifat } \\
\text { Interaktif dan Dinamis }\end{array}$ & 15 & 4 & 1 \\
\hline 2 & $\begin{array}{l}\text { Aplikasi membantu } \\
\text { informasi mutu air } \\
\text { mineral berdasarkan PH } \\
\text { Air }\end{array}$ & 16 & 4 & 0 \\
\hline 3 & $\begin{array}{l}\text { Digunakan sebagai media } \\
\text { teknologi informasi mutu } \\
\text { air mineral menggunakan } \\
\text { Fuzzy Tsukamoto }\end{array}$ & 5 & 14 & 1 \\
\hline 4 & Warna tampilan menarik & 5 & 10 & 5 \\
\hline 5 & $\begin{array}{l}\text { Menu tampilan bersifat } \\
\text { user friendly }\end{array}$ & 6 & 13 & 1 \\
\hline \multicolumn{2}{|l|}{ Jumlah Responden } & \multicolumn{2}{|c}{} \\
\hline
\end{tabular}

Maka diperoleh jawaban sangat menarik $47 \%$, menarik $45 \%$, dan tidak menarik $8 \%$. Adapun cara perhitungannya adalah sebagai berikut :

1. Hitung setiap row pernyataan kemudian pernyataan dijumlahkan.

2. Lakukan penghitungan

a. Sangat Menarik : $\frac{47}{100} \times 100=47 \%$

b. Menarik : $\frac{45}{100} \times 100=45 \%$

c. Tidak Menarik : $\frac{8}{100} \times 100=8 \%$

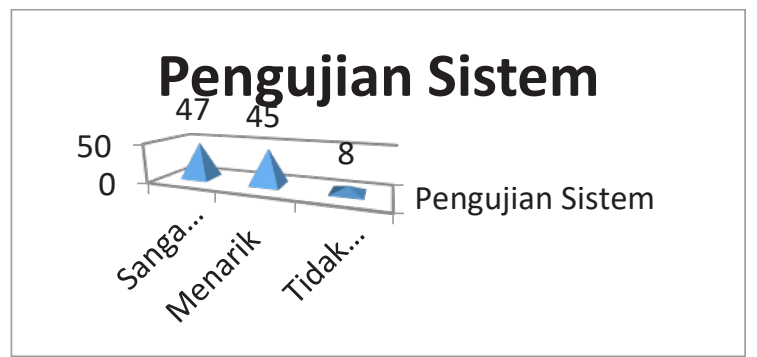

Gambar 6. Diagram Persentase Pengujian Sistem WhiteBook Testing

\section{Penutur}

\section{A. Kesimpulan}

Dari hasil penelitian yang telah dilakukan dapat diambil beberapa kesimpulan yaitu :

1. Setelah dilakukan 7 (tujuh) kali percobaan dari jam 01.00 sampai jam 24.00 dengan tingkat $\mathrm{pH}$ berkisar 35.7 sampai 48.5, sisa chlor 0, DHL berkisar 208 sampai 226.3, TDS berkisar 104 sampai 117.5 ,mutu air antara 7.126 sampai 7.904 keterangan mutu air baik dengan ketentuan Kualitas mutu air yang baik berdasarkan NTU yang memiliki nilai minimal 0 dan maksimal 5.

2. Dari hasil pengujian sistem diperoleh jawaban sangat menarik $47 \%$, menarik $45 \%$, dan tidak menarik $8 \%$.

3. Faktor Utama penentuan mutu air adalah sumber air baku itu sendiri, semakin sedikit pencemaran di hilirnya maka semakin bagus mutu air yang dihasilkan.

\section{B. Saran}

Diharapkan pengembangan aplikasi ini dapat menjadi referensi bukan hanya mutu air mineral PDMA tetapi air miniral yang dijual dalam kemasan dengan merk tertentu dengan metode selain Tsukamoto, sehingga dapat memperoleh perkembangan informasi teknologi, diharapkan aplikasi ini bisa dikembangkan lebih lanjut.

\section{Daftar Pustaka}

Abdurrahman Ginanjar, 2011, Penerapan Metode Tsukamoto (Logika Fuzzy) dalam Sistem Pendukung Keputusan untuk Menetukan Jumlah Produksi Barang Berdasarkan Data persediaan dari Jumlah Permintaan, Universitas Negeri Yogyakarta, Yogyakarta. 17-18

Evaluasi Air Sungai Bawah Tanah Seropan Sebagai Sumber Air Minum Perusahan Daerah Air Minum (PDAM) Sub Sistem Seropan Kabupaten Gunung Kidul, 2015, Repository.Ugm.ac.id, Yogyakarta. 12-17

Maryaningsih, Siswanto, Masterjon, 2013, Metode Logika Fuzzy Tsukamoto Dalam Sistem Pengambilan Keputusan Penerimaan Beasiswa, No. 9, Vol. 1 Februari 2013, Media Infotama, Universitas Dehasen, Bengkulu. 143-146

Maulana. Yaumas, Nur Hadiyono, 2014, Implementasi Fuzzy Tsukamoto dalam Mendiagnosa Penyakit Diabetes Melitus, Universitas Dian Nuswantoro, Semarang, 3-4

Peraturan Menteri Kesehatan Republik Indonesia Nomor 492/Menkes/Per/2010.

Wandrivel Rido, Suhartuti Netty, Lestari yuniar, 2013, Kualitas Air Minum yang Di Produksi Air Minum Isi Ulang di Kecamatan Bungus Padang Berdasarkan Persyaratan Mikrobiologi, Jurnal.fk.unan.ac.id, Padang. 130-131 